\title{
RADIONUCLIDE LEACHING FROM ORGANIC ION EXCHANGE RESIN
}

CH Delegard

DE Rinehart

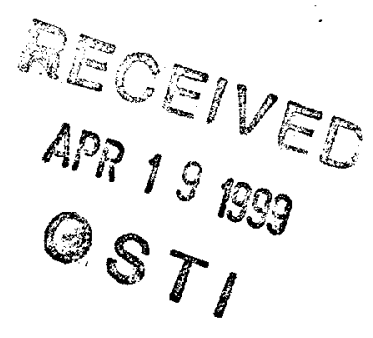

July 24, 1998

Prepared for

Numatec Hanford Corporation

Work Supported by

the U.S. Department of Energy

under Contract DE-AC06-76RLO 1830

Pacific Northwest National Laboratory

Richland, Washington 99352 


\title{
DISCLAIMER
}

This report was prepared as an account of work sponsored by an agency of the United States Government. Neither the United States Government nor any agency thereof, nor Battelle Memorial Institute, nor any of their employees, makes any warranty, express or implied, or assumes any legal liability or responsibility for the accuracy, completeness, or usefulness of any information, apparatus, product, or process disclosed, or represents that its use would not infringe privately owned rights. Reference herein to any specific commercial product, process, or service by trade name, trademark, manufacturer, or otherwise does not necessarily constitute or imply its endorsement, recommendation, or favoring by the United States Government or any agency thereof, or Battelle Memorial Institute. The views and opinions of authors expressed herein do not necessarily state or reflect those of the United States Government or any agency thereof.

\author{
PACIFIC NORTHWEST NATIONAL LABORATORY \\ operated by \\ BATTELLE \\ for the \\ UNITED STATES DEPARTMENT OF ENERGY \\ under Contract DE-AC06-76RLO 1830
}

Printed in the United States of America

Available to DOE and DOE contractors from the

Office of Scientific and Technical Information, P.O. Box 62, Oak Ridge, TN 37831:

prices available from (615) 576-8401.

Available to the public from the National Technical Information Service, U.S. Department of Commerce, 5285 Port Royal Rd., Springfield, VA 22161

This document was printed on recycled paper. 


\section{DISCLAIMER}

Portions of this document may be illegible in electronic image products. Images are produced from the best available original document. 


\section{Summary and Conclusions}

Laboratory tests were performed to examine the efficacy of leach treatments for decontaminating organic ion exchange resins (OIER), which have been found in a number of samples retrieved from $\mathrm{K}$ East Basin sludge. Based on process records, the OIER found in the $\mathrm{K}$ Basins is a mixed-bed, strong acid/strong base material marketed as Purolite ${ }^{\mathrm{TM}}$ NRW-037. Radionuclides sorbed or associated with the OIER can restrict its disposal to the Environmental Restoration Disposal Facility (ERDF). The need for testing to support development of a treatment process for $\mathrm{K}$ Basin sludge has been described in Section 4.2 of "Testing Strategy to Support the Development of K Basins Sludge Treatment Process" (Flament 1998).

To help understand the effects of anticipated OIER elutriation and washing, tests were performed with well-rinsed OIER material from K East Basin floor sludge (sample H-08 BEAD G) and with well-rinsed OIER having approximately $5 \%$ added $\mathrm{K}$ East canister composite sludge (sample KECOMP). The rinsed resin-bearing material also contained the inorganic ion exchanger Zeolon- $900^{\mathrm{TM}}$, a zeolite primarily composed of the mineral mordenite. The zeolite was estimated to comprise 27 weight percent of the dry H-08 BEAD G material.

Based on the recommendations of separate engineering studies, two leach treatment methods were tested. In the first method, $6 \mathrm{M} \mathrm{HNO} / 2 / 4 \mathrm{M} \mathrm{Ce}(\mathrm{IV})$ was contacted with the OIER and with the sludge-amended OIER. In the second method, sequential leach contacts with $4 \underline{\mathrm{M}} \mathrm{HNO}_{3}$ followed by $0.1 \underline{\mathrm{M} \mathrm{HNO}} \mathrm{HN}_{3} / 0.2 \underline{\mathrm{M}}$ $\mathrm{H}_{2} \mathrm{C}_{2} \mathrm{O}_{4}$ were performed with the OIER and sludge-amended OIER. All leach tests were performed in duplicate at about $28^{\circ} \mathrm{C}$ for 4 hours contact time using approximately $5 \mathrm{~mL}$ leachant per gram of OIER. Tests with added sludge included about 0.05 grams of $\mathrm{K}$ East canister composite sludge.

The two-step nitric/oxalic acid treatment generally gave better overall solids decontamination than the $\mathrm{Ce}$ (IV) treatment. The presence of added sludge severely increased the concentrations of uranium, plutonium, and americium in the treated residues. In particular, the TRU concentrations in the residues were consistently lower for the nitric/oxalic treatment than for the Ce(IV) treatment. The better performance of nitric/oxalic is almost solely because of its better removal of plutonium. This observation is true for the tests both with and without added sludge.

The nitric/oxalic acid treatment of OIER alone met the Environmental Restoration Disposal Facility (ERDF) criteria for uranium, ${ }^{239} \mathrm{Pu}$, and TRU. The criterion was exceeded about 1.2 -fold for ${ }^{137} \mathrm{Cs}$ and 1.8-fold for ${ }^{241} \mathrm{Am}$. With sludge added, the ERDF criteriion was exceeded 2- to 3-fold for ${ }^{137} \mathrm{Cs}, 1.5$ - to 3fold for uranium, 3- to 7-fold for ${ }^{239} \mathrm{Pu}$, up to 35-fold for ${ }^{241} \mathrm{Am}$, and 11- to 18-fold for TRU.

Comparison of the test data for the leachants showed that better ${ }^{137} \mathrm{Cs}$ and ${ }^{241} \mathrm{Am}$ decontamination can be obtained by leaching at higher acid concentrations. The ${ }^{137} \mathrm{Cs}$ concentrations range from about 12 to 100 $\mu \mathrm{Ci} / \mathrm{g}$ or about 12 to $100 \mu \mathrm{Ci} / \mathrm{mL}$, assuming a $1.0-\mathrm{g} / \mathrm{mL}$ bulk density of the largely resin residue. The ERDF criterion $(32 \mu \mathrm{Ci} / \mathrm{mL})$ was exceeded 2 - to 3 -fold for ${ }^{137} \mathrm{Cs}$ in the nitric/oxalic acid tests with added sludge. The $\mathrm{Ce}(\mathrm{IV})$ leach, with its higher nitric acid concentration, achieved better ${ }^{137} \mathrm{Cs}$ decontamination and produces solids near the ERDF ${ }^{137} \mathrm{Cs}$ criterion.

Though americium leaching improved with increasing acid concentration, concentrations in the final residues are not strongly dependent on whether the one-step $\mathrm{Ce}(\mathrm{IV})$ treatment or the two-step nitric/oxalic acid treatment is used. The americium concentrations from the nitric/oxalic acid treatment are up to 1.8 times the $50 \mathrm{nCi} / \mathrm{mL}$ ERDF limit in the tests without added sludge and up to 35 times the ERDF limit in the tests with sludge. 
The plutonium concentrations in the nitric/oxalic acid-treated residues from tests without added sludge are below the ERDF criterion of $29 \mathrm{nCi} / \mathrm{mL}$ each ${ }^{239} \mathrm{Pu}$ and ${ }^{240} \mathrm{Pu}$. Because ${ }^{240} \mathrm{Pu}$ represents about $1 / 3$ of the ${ }^{239,240} \mathrm{Pu}$ activity in $\mathrm{K}$ Basins materials, and the ERDF activity concentration limits for ${ }^{239} \mathrm{Pu}$ and ${ }^{240} \mathrm{Pu}$ are identical, the ${ }^{239} \mathrm{Pu}$ limit is the more restrictive for ERDF disposal acceptance. The ${ }^{239} \mathrm{Pu}$ limit is exceeded about 3- to 7-fold for the residues from nitric/oxalic acid tests containing the added sludge.

Uranium decontamination was better for the nitric/oxalic treatment than for the $\mathrm{Ce}$ (IV) treatment. The ERDF criterion for uranium $(2,600 \mu \mathrm{g} / \mathrm{mL})$ was exceeded 1.4- to 10 -fold for the tests having added sludge; the tests without sludge were about half the ERDF limits. 


\section{CONTENTS}

Summary and Conclusions ...................................................................ii

1.0 Background and Approach................................................................ 1

2.0 Experimental Materials and Methods.............................................. 3

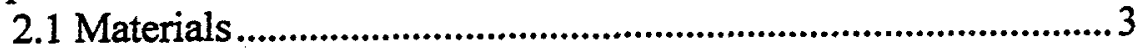

2.2 Leaching Experimental Procedure .......................................... 3

2.3 Analyses .......................................................................... 4

3.0 Experimental Results and Discussion .................................................5

3.1 Qualitative Observations .......................................................5

3.2 Analyses and Composition of Starting Materials.....................5

3.3 Leachate Analyses............................................................... 7

3.4 Leach Residue Analyses.......................................................8

3.5 Material Balances ............................................................... 9

3.6 Decontamination Factors................................................. 11

3.7 Distribution Coefficients .................................................. 12

3.8 Dissolution Coefficients ..................................................... 13

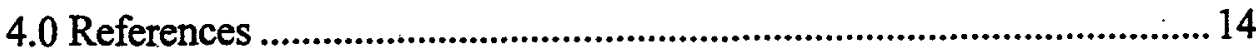

\section{TABLES}

Table 1. Leachants and Material Weights in Leach Testing ...................... 4

Table 2. Radiochemical Concentrations and Quantities in the Starting Materials ............................................................6

Table 3. Metal Concentrations in Solids ................................................. 7

Table 4. Radiochemical Concentrations in Test Leachates........................8

Table 5. Radiochemical Concentrations in Test Residues ..........................8

Table 6. Leach Testing Material Balance for ${ }^{137} \mathrm{Cs}$.....................................9

Table 7. Leach Testing Material Balance for Uranium............................ 10

Table 8. Leach Testing Material Balance for ${ }^{239,240} \mathrm{Pu}$.............................. 10

Table 9. Leach Testing Material Balance for ${ }^{241} \mathrm{Am}$................................ 10

Table 10. Leach Testing Material Balance for ${ }^{238} \mathrm{Pu} /{ }^{241} \mathrm{Am}$..................... 11

Table 11. Leach Testing Material Balance for Total Alpha...................... 11

Table 12. Decontamination Factors for Solids........................................ 11

Table 13. Distribution Coefficients ......................................................... 12

Table 14. Dissolution Coefficients ........................................................ 13 


\subsection{Background and Approach}

Tests were conducted using organic ion exchange resin (OIER)-bearing genuine sludges from the $\mathrm{K}$ Basins to examine the efficacy of alternative decontamination methods. Background information, the experiments performed, and experimental results are presented in this report.

Solids, including OIER, to be delivered to the Environmental Restoration Disposal Facility (ERDF) from chemical treatment of K Basin sludge must meet Waste Acceptance Criteria (WAC) for radionuclide concentrations (ERDF 1997). The radionuclides most likely limiting the ERDF acceptance of K Basin solid residues are ${ }^{137} \mathrm{Cs}\left(32 \mathrm{Ci} / \mathrm{m}^{3}\right.$ or $\left.32 \mu \mathrm{Ci} / \mathrm{mL}\right)$ and the transuranics (TRU; $100 \mathrm{nCi} / \mathrm{g}$ ). The TRU isotopes have individual limits: ${ }^{241} \mathrm{Am}, 0.05 \mathrm{Ci} / \mathrm{m}^{3}(50 \mathrm{nCi} / \mathrm{mL}) ;{ }^{238} \mathrm{Pu}, 1.5 \mathrm{Ci} / \mathrm{m}^{3}(1500 \mathrm{nCi} / \mathrm{mL})$; and ${ }^{239} \mathrm{Pu}$ and ${ }^{240} \mathrm{Pu}, 0.029 \mathrm{Ci} / \mathrm{m}^{3}(29 \mathrm{nCi} / \mathrm{mL})$ each. The effective uranium limit for disposal to ERDF, $0.0026 \mathrm{~g} \mathrm{U} / \mathrm{mL}^{1}$, has the potential to restrict certain $\mathrm{K}$ Basins residues. The final waste form for residual solids (of which OIER will be a constituent) must meet these levels to allow disposal to ERDF. A sum of fractions criterion likely will be applied.

The radionuclide contamination associated with the OIER may be physically adsorbed as radioactive particles or may be ion exchanged on the OIER itself. Rinsing in the OIER/sludge separation (elutriation) step will achieve some physical removal of the adsorbed radioactive particles. The remaining radioactivity associated with non-OIER particles, not removed by elutriation, must be decontaminated to ERDF-acceptable levels by, for example, acid leaching. The radionuclides associated with the OIER may be dissolved from the OIER by various methods such as dissolution of the OIER, defunctionalization of the OIER (to destroy its ion exchange capacity), or elution. Because of the demonstrated ruggedness of the OIER to destruction or defunctionalization in hot concentrated nitric acid (Pool et al. 1998), elution was chosen for decontaminating OIER (Dodd 1998).

The TRU concentrations in water-rinsed and dried OIER taken from the $\mathrm{K}$ East Basin (sample KES-H08) range from $647-844 \mathrm{nCi} / \mathrm{g}$. Unrinsed OIER contains $144 \mu \mathrm{Ci}{ }^{137} \mathrm{Cs}$ and $0.003 \mathrm{~g} \mathrm{U}$ per gram of dried resin (Schmidt et al. 1999). Sample KES-H-08 also contains irregularly shaped white granules approximately $1 \mathrm{~mm}$ long. The granules have been identified by X-ray diffraction (XRD) as mordenite and arise from use of Norton Industries Zeolon- $900^{\mathrm{TM}}$ in the treatment of $\mathrm{K}$ Basin water to remove ${ }^{137} \mathrm{Cs}$ (Schmidt et al. 1998).

Tests on the elution/loading behavior of sample KES-H-08 (OIER and contained Zeolon-900 ${ }^{\mathrm{rM}}$ ) on contact with $10 \underline{\mathrm{M} \mathrm{HNO}}$ followed by $10 \underline{\mathrm{M}}$ acid and water rinsing have been conducted in prior scoping studies (Schmidt et al. 1999). About $80 \%$ of the U, $25 \%$ of the Pu, and $70 \%$ or more of the Am were removed at ratios of about $1 \mathrm{~g}$ resin per $20 \mathrm{~mL}$ acid. Cesium distributions were unmeasured, but high removals would be expected from the OIER and low removals from the zeolite. Residual activities in the acid-treated OIER were $110-190 \mathrm{nCi}{ }^{239,240} \mathrm{Pu} / \mathrm{g}, 20-120 \mathrm{nCi}^{241} \mathrm{Am} / \mathrm{g}$, and $1.5-34 \mu \mathrm{Ci}{ }^{137} \mathrm{Cs} / \mathrm{g}$. Uranium concentrations were undetectable but likely were near $0.0003 \mathrm{~g} \mathrm{U} / \mathrm{g}$ based on $\mathrm{K}_{\mathrm{d}}$ tests at higher loadings. Therefore, multiple washing contacts of OIER with strong $\mathrm{HNO}_{3}$ may remove $\mathrm{Cs}, \mathrm{U}$, and Am

\footnotetext{
${ }^{1}$ The ERDF WAC limit for ${ }^{238} \mathrm{U}$ and its daughters is $0.012 \mathrm{Ci} / \mathrm{m}^{3}$. With 8 alpha and 6 beta decays in the ${ }^{238} \mathrm{U}$ decay chain and a specific activity of $3.36 \times 10^{-7} \mathrm{Ci}{ }^{238} \mathrm{U} / \mathrm{g}$, the specific activity of the ${ }^{238} \mathrm{U}$ chain is $4.7 \times 10^{-6} \mathrm{Ci} / \mathrm{g}$. The ERDF limit for ${ }^{238} \mathrm{U}$ thus is $0.00256 \mathrm{~g}^{238} \mathrm{U} / \mathrm{mL}$. The ERDF limit for ${ }^{235} \mathrm{U}$ (daughters not included) is 0.0027 $\mathrm{Ci} / \mathrm{m}^{3}$ and the specific activity of ${ }^{235} \mathrm{U}$ is $2.16 \times 10^{-6} \mathrm{Ci} / \mathrm{g}$. Thus the ERDF limit for ${ }^{235} \mathrm{U}$ is $0.0013 \mathrm{~g}{ }^{235} \mathrm{U} / \mathrm{mL}$. The relative limits of the two uranium isotopes, and the nominal $0.7 \%{ }^{235} \mathrm{U}$ enrichment of the $\mathrm{K}$ Basins sludge, mean that ${ }^{238} \mathrm{U}$ concentration limits ERDF disposal. Therefore, the effective uranium limit for disposal to ERDF is $0.0026 \mathrm{~g} \mathrm{U} / \mathrm{mL}$.
} 
to meet ERDF criteria. However, such an approach would be less successful for Pu where strong anion exchange sorption occurs at high $\mathrm{HNO}_{3}$ concentrations.

To remove $\mathrm{Cs}, \mathrm{U}, \mathrm{Am}$, and particularly $\mathrm{Pu}$ activity from mixed bed OIER, conditions must be selected to minimize sorption on the respective anion and cation components. At high $\mathrm{HNO}_{3}$ concentrations, anion resin sorption is high for $\mathrm{Pu}$ with some sorption of $\mathrm{U}$; $\mathrm{Cs}$ and Am sorption is insignificant. Sorption of $\mathrm{Cs}, \mathrm{U}, \mathrm{Pu}$, and $\mathrm{Am}$ on cation resin is low at high acid concentrations. At low acid concentrations, sorption of $\mathrm{Cs}, \mathrm{U}, \mathrm{Pu}$, and Am on anion resin is low but is high on cation resin. Therefore, to remove these radioelements from mixed resin, a two-step sequence of strong $\mathrm{HNO}_{3}$ followed by dilute $\mathrm{HNO}_{3}$ treatment was initially envisioned. The dilute acid concentration must not be lower than $0.5 \mathrm{M} \mathrm{HNO}$ to thwart $\mathrm{Pu}(\mathrm{IV})$ polymerization. To prevent sorption of $\mathrm{Pu}$ on the cation resin at low $\mathrm{HNO}_{3}$ concentrations, a complexant for Pu may be added to decrease the effective charge. A possible complexant is oxalate. Maximum formation of the charge-neutral $\left[\mathrm{Pu}\left(\mathrm{C}_{2} \mathrm{O}_{4}\right)_{2}\right]^{0}$ complex in $0.75 \underline{\mathrm{M}}$ $\mathrm{HNO}_{3}$ occurs at about 0.005 to $0.01 \mathrm{M} \mathrm{H}_{2} \mathrm{C}_{2} \mathrm{O}_{4}$ (Reas 1949).

An engineering study was performed to identify chemical agents to leach or elute radioactive components from both cation and anion exchange resin (Dodd 1998). The study considered that rinsing of other solid sludge components from the resin may not be perfect and that two cases of resin isolation exist; class separation of the anion from the cation resins and no separation of the anion and cation resins. ${ }^{2}$ To be conservative, it was assumed that resin may not be separable under plant conditions. In that event, the mixed (anion plus cation) resins must be treated. In the end, two alternatives were proposed to treat mixed resin (Dodd 1998).

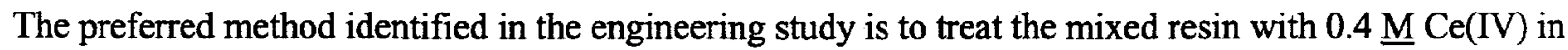
$6 \underline{\mathrm{M} \mathrm{HNO}}$. The strong acid would displace $\mathrm{Cs}, \mathrm{U}, \mathrm{Pu}$, and $\mathrm{Am}$ sorbed on the cation resin, as described previously. In $6 \mathrm{M} \mathrm{HNO}, \mathrm{Ce}(\mathrm{IV})$ has a distribution coefficient $\left(\mathrm{K}_{\mathrm{d}}\right)$ of about $200 \mathrm{~mL} / \mathrm{g}$ on anion resin by its formation of an anionic nitrate complex (Roberts 1963). The Ce(IV) would remove the Pu from the anion resin by two mechanisms: mass action displacement of the $\mathrm{Pu}(\mathrm{IV})$ complex and oxidation of the $\mathrm{Pu}(\mathrm{IV})$ to $\mathrm{Pu}(\mathrm{VI})$. The $\mathrm{Pu}(\mathrm{VI})$ forms an anionic nitrate complex, $\left[\mathrm{PuO}_{2}\left(\mathrm{NO}_{3}\right)_{4}\right]^{2-}$, which is less strongly sorbed in $6 \underline{\mathrm{M}} \mathrm{HNO}_{3}\left(\mathrm{~K}_{\mathrm{d}} \cong 4\right)$ than the $\mathrm{Pu}(\mathrm{IV})$ nitrate complex $\left(\mathrm{K}_{\mathrm{d}} \cong 1000\right)$.

The second proposed option for the mixed resin is to treat with two steps. The initial step would be exposure to strong ( $>3 \mathrm{M}) \mathrm{HNO}_{3}$. This would displace the cations (Cs, U, Pu, Am) from the cation resin. The second step would use $0.1 \underline{\mathrm{M}} \mathrm{HNO}_{3}$ with $0.2 \underline{\mathrm{M}}$ oxalic acid to form the sufficiently soluble and charge-neutral $\left[\mathrm{Pu}\left(\mathrm{C}_{2} \mathrm{O}_{4}\right)_{2}\right]^{0}$ oxalate complex. Acid exchanged from the resin (Donen effect) would

${ }^{2}$ A class segregation of the anion from the cation resin might be accomplished based on particle density differences (1.08 and $1.29 \mathrm{~g} / \mathrm{mL}$, respectively, in water), by cycloning, or by elutriation (sluicing). Based on these relative particle densities, and because strong $\mathrm{HNO}_{3}$ is a good eluant for cation resin, addition of the mixed resin to high concentration $\mathrm{HNO}_{3}$ solutions may be used to float the anion resin from the cation resin. Tests in which the

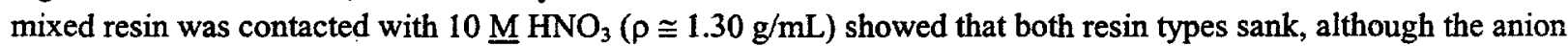
resin showed buoyancy in swirling (Schmidt et al. 1999). Segregation of floating anion from cation resin occurred upon contact with concentrated $\mathrm{HNO}_{3}$, which has a density of about $1.46 \mathrm{~g} / \mathrm{mL}$ (Pool et al. 1998). Shrinkage of anion resin is known to occur on contact with strong nitric acid (Ryan 1972).

After contact with concentrated $\mathrm{HNO}_{3}$, the cation resin would be stripped of $\mathrm{Cs}, \mathrm{U}, \mathrm{Pu}$, and $\mathrm{Am}$. However, the anion resin would strongly sorb $\mathrm{Pu}$ at these conditions. The floating anion resin could be skimmed from the concentrated $\mathrm{HNO}_{3}$ and then contacted with $0.1 \mathrm{M} \mathrm{HNO}_{3}$ to elute the $\mathrm{Pu}\left(\mathrm{HNO}_{3}\right.$ desorbed from the resin would raise solution $\mathrm{HNO}_{3}$ concentrations to approach $0.5 \underline{\mathrm{M}}$ ). Subsequent contacts of the cation resin with $6 \underline{\mathrm{M}} \mathrm{HNO}_{3}$ and the anion resin with $0.5 \underline{\mathrm{M} \mathrm{HNO}} 3$ could further decrease the radionuclide concentrations on these separate resin fractions. 
increase the effective $\mathrm{HNO}_{3}$ concentration above the $0.1 \mathrm{M} \mathrm{HNO}_{3}$ added. Because the plutonium complex is uncharged, it would have little affinity for either the anion or cation resins and would cause the plutonium to partition to the solution.

\subsection{Experimental Materials and Methods}

Approved Test Instructions were followed to prepare the KES-H-08 material for testing and to perform the leach contact tests. All testing and analyses were performed in the Radiochemical Processing Laboratory (RPL). The leach contacts were made in the RPL shielded analytical laboratory hot cell facility.

\subsection{Materials}

Material taken from the characterized and sieved KES-H-08 (H-08) K East Basin sample was used as the source of the OIER in these tests. The H-08 material first was rinsed of adsorbed sludge particles. Specifically, two 13 -gram portions of as-received H-08 sample were placed separately on a Tyler 42 sieve ( $346 \mu \mathrm{m}$ mesh opening). Distilled and deionized (DI) water $(\sim 100$ to $150 \mathrm{~mL})$ was flowed over each sample by use of a plastic squirt bottle. The washed sample showed mixed cation (dark) and anion (amber-colored) resin, with white Zeolon- $900^{\mathrm{TM}}$ grains also plainly visible. The rinse waters were turbid. Very little resin passed through the sieve but some brown-colored irregular-shaped granules were found. The rinsed sample's appearance was identical to that found in earlier tests (Figure 2.1 in Schmidt et al. 1999). The solids were drained on the sieve and the two rinsed portions collected in a single jar. The rinsed material was designated H-08 BEAD G, and two sample aliquots were taken for analysis.

The KECOMP material is a composite of canister sludges taken from the K East Basin. The KECOMP is about 42 weight percent uranium.

Leach solutions were prepared using DI water and reagent-grade chemicals: crystalline ceric ammonium nitrate $\left[\left(\mathrm{NH}_{4}\right)_{2} \mathrm{Ce}\left(\mathrm{NO}_{3}\right)_{6}\right]$, crystalline oxalic acid $\left(\mathrm{H}_{2} \mathrm{C}_{2} \mathrm{O}_{4} \cdot 2 \mathrm{H}_{2} \mathrm{O}\right)$, and $15.9 \mathrm{M}$ nitric acid $\left(\mathrm{HNO}_{3}\right)$ solution. The leachants were $6 \underline{\mathrm{M}} \mathrm{HNO}_{3} / 0.4 \underline{\mathrm{M}}\left(\mathrm{NH}_{4}\right)_{2} \mathrm{Ce}\left(\mathrm{NO}_{3}\right)_{6}, 4 \underline{\mathrm{M}} \mathrm{HNO}_{3}$, and $0.1 \underline{\mathrm{M}} \mathrm{HNO}_{3} / 0.2 \underline{\mathrm{M}}$ $\mathrm{H}_{2} \mathrm{C}_{2} \mathrm{O}_{4}$. Reagents were prepared quantitatively $( \pm 0.0001$ gram $)$ using a Mettler AE 240 balance, calibrated pipets, and volumetric glassware. The $\mathrm{Ce}(\mathrm{IV})$ leach solution was near saturation in ceric salt; separate tests showed the solubility to be less than $0.5 \underline{\mathrm{M}} \mathrm{Ce}(\mathrm{IV})$ in $6 \underline{\mathrm{M}} \mathrm{HNO}_{3}$.

\subsection{Leaching Experimental Procedure}

The leach testing was performed in duplicate for each test condition. First, 1-gram aliquots of rinsed resin (H-08 BEAD G) were weighed $( \pm 0.0001$ gram) into eight tare-weighed $15-\mathrm{mL}$ capped polystyrene centrifuge cones. To four of the cones, $\sim 0.05$ grams of sludge sample KECOMP were added and the weights ( \pm 0.0001 gram) measured. The KECOMP material, a composite of $\mathrm{K}$ East Basin canister sludge samples, was characterized for radioelement concentrations in separate testing. Four tests (duplicate tests with and without added KECOMP sludge) were performed with each of the $\mathrm{Ce}(\mathrm{IV})$ and nitric/oxalic acid leachants. The test matrix, weights of H-08 BEAD G and KECOMP materials used in the individual tests, and the respective leachants are described in Table 1. 
Table 1. Leachants and Material Weights in Leach Testing

\begin{tabular}{|c|c|c|c|c|}
\hline \multirow[b]{2}{*}{ Test } & \multicolumn{2}{|c|}{ Leachant } & \multicolumn{2}{|c|}{ Material Mass, grams } \\
\hline & First Leach & Second Leach & H-08 BEAD G & KECOMP \\
\hline$\overline{\text { OIER } 1}$ & $6 \mathrm{M} \mathrm{HNO}_{3} /$ & None & 1.0532 & 0 \\
\hline OIER 2 & $0.4 \underline{\mathrm{M}} \mathrm{Ce}(\mathrm{IV})$ & & 1.3477 & $\overline{0}$ \\
\hline OIER 3 & & & 1.2735 & 0.0761 \\
\hline OIER 4 & & & 1.1099 & 0.0457 \\
\hline OIER 5 & $4 \underline{\mathrm{M} \mathrm{HNO}}$ & $0.1 \underline{\mathrm{M} \mathrm{HNO}_{3} /}$ & 0.9759 & 0 \\
\hline OIER 6 & & $0.2 \underline{\mathrm{M}} \mathrm{H}_{2} \mathrm{C}_{2} \mathrm{O}_{4}$ & 1.2402 & 0 \\
\hline OIER 7 & & & 1.0231 & 0.0382 \\
\hline OIER 8 & & & 1.1653 & 0.0681 \\
\hline
\end{tabular}

All leach contacts of the resin or resin with sludge were conducted at ambient hot cell temperature $\left(-28^{\circ} \mathrm{C}\right)$ with 4-hour contact times and $5 \mathrm{~mL}$ of leachant. The test centrifuge cones were agitated hourly to achieve mixing but were left in racks with caps slightly open between agitations to allow offgassing.

After 4 hours contact with Ce(IV) leachant, the solids were separated from the solution by vacuum filtration and washed five times with $1-\mathrm{mL}$ aliquots of DI water poured over the solids on the filters. The washed residues were air-dried on the filters and reweighed in the hot cell in preparation for analysis. The solutions (leachate with rinses added) were weighed and collected for analysis.

In the two-contact tests with nitric and oxalic acids, the first leachant $\left(4 \underline{\mathrm{M} \mathrm{HNO}} \mathrm{H}_{3}\right)$ was removed from the solids by centrifugation and decantation by transfer pipet. The solutions were withdrawn by placing the pipet tip at the centrifuge cone bottom and carefully suctioning the solution. This technique essentially drained the interstitial liquid from the resin. The solids were washed, centrifuged, and decanted by pipet in the same manner in their respective centrifuge cones with three 1-mL aliquots of $4 \mathrm{M} \mathrm{HNO}_{3}$. The washes were added to the $4 \underline{\mathrm{M}} \mathrm{HNO}_{3}$ leachate. The second leachant $\left(0.1 \underline{\mathrm{M}} \mathrm{HNO}_{3} / 0.2 \underline{\mathrm{M} \mathrm{H}} \mathrm{H}_{2} \mathrm{C}_{4}\right)$ then was added to the solids. After 4 hours contact, the solids were separated from the solution by vacuum filtration and washed on the filters twice with $1-\mathrm{mL}$ aliquots of DI water. The washes were added to the second leachate. The washed solids were air-dried at ambient hot cell temperatures and reweighed in preparation for analysis. The two leachates with contained rinses for each test also were weighed and collected for analysis.

\subsection{Analyses}

The radiochemical analyses were performed in the RPL analytical laboratory using established procedures.

Two portions of the moist $\mathrm{H}-08 \mathrm{BEAD} \mathrm{G}$ were analyzed to determine concentrations of uranium, radionuclides $\left({ }^{241} \mathrm{Am},{ }^{239,240} \mathrm{Pu},{ }^{238} \mathrm{Pu}\right.$, and ${ }^{137} \mathrm{Cs}$ ), and water. Water concentration was determined by measuring the mass loss caused by drying weighed solids aliquots in an oven overnight at $105^{\circ} \mathrm{C}$. The dried samples then were digested by fusion in molten $\mathrm{KOH}$ followed by acid dissolution. The fused and dissolved materials were analyzed for uranium concentration by time-resolved laser fluorimetry, ${ }^{137} \mathrm{Cs}$ and ${ }^{241} \mathrm{Am}$ concentrations by gamma energy analyses (GEA), and total alpha, ${ }^{239,240} \mathrm{Pu}$, and ${ }^{238} \mathrm{Pu} /{ }^{241} \mathrm{Am}$ concentrations by alpha energy analyses (AEA). These solids also were analyzed to determine bulk metal concentrations by inductively coupled plasma - atomic energy spectrometry (ICP-AES). 
The residual solids remaining from the eight leach tests were digested by fusion in molten $\mathrm{KOH}$ followed by acid dissolution in the same manner as the H-08 BEAD G material. For tests OIER 1 through OIER 4, which used Ce(IV) leachant, about $50 \mu \mathrm{L}$ concentrated HF solution were required to clarify the fusion digest solution of fine white solids. The refractory solids evidently were $\mathrm{CeO}_{2}$ formed in the fusion. The digestates were analyzed for uranium concentration by time-resolved laser fluorimetry, ${ }^{137} \mathrm{Cs}$ and ${ }^{241} \mathrm{Am}$ concentrations by GEA, and total alpha, ${ }^{239,240} \mathrm{Pu}$, and ${ }^{238} \mathrm{Pu} /{ }^{241} \mathrm{Am}$ concentrations by AEA.

The leachates were analyzed to determine uranium, ${ }^{137} \mathrm{Cs},{ }^{241} \mathrm{Am}$, total alpha, ${ }^{239,240} \mathrm{Pu}$, and ${ }^{238} \mathrm{Pu} /{ }^{241} \mathrm{Am}$ concentrations by the same analytical techniques as used for the digested solids.

\subsection{Experimental Results and Discussion}

Experimental observations of the qualitative behavior and radiochemical distributions in the leach testing are presented and interpreted.

\subsection{Qualitative Observations}

Bubbling was observed upon contact of the H-08 BEAD G, with or without added KECOMP sludge, with both the $6 \underline{\mathrm{M} \mathrm{HNO}} 3 / 0.4 \underline{\mathrm{M} \mathrm{Ce}}(\mathrm{TV})$ and $4 \underline{\mathrm{M}} \mathrm{HNO}_{3}$ leachants. Bubbling continued for the duration of the tests with the $\mathrm{Ce}(\mathrm{IV})$ leachant but was much less for the tests without added sludge. The bubbling only occurred within the first hour of contact with the $4 \underline{\mathrm{M}} \mathrm{HNO}_{3}$ leachant. No bubbling at all was observed with the second contact leachant, $0.1 \mathrm{M} \mathrm{HNO} / 0.2 \mathrm{M} \mathrm{H}_{2} \mathrm{C}_{2} \mathrm{O}_{4}$.

Much of the amber-colored anion exchange resin was observed to float in the $6 \underline{\mathrm{M}} \mathrm{HNO}_{3} / 0.4 \underline{\mathrm{M}} \mathrm{Ce}$ (IV) leachant, even after 4 hours contact. Some flotation was caused by adhesion of bubbles on the resin. However, agitation to disengage the bubbles sunk some, but not all, of the floating resin. Some flotation of anion exchange resin also was observed initially in the $4 \mathrm{M} \mathrm{HNO}_{3}$ but no floating resin was observed after 1 hour of contact. No resin floated in tests with $0.1 \underline{\mathrm{M} \mathrm{HNO}} 3 / 0.2 \underline{\mathrm{M} \mathrm{H}} \mathrm{H}_{2} \mathrm{O}_{4}$. Neither the darkcolored cation resin nor the zeolite granules floated in any test.

Tests with added sludge (OIER 3, 4, 7, and 8) produced turbid solutions; solutions from the analogous tests without added sludge were clear.

\subsection{Analyses and Composition of Starting Materials}

Results of the water and radiochemical analyses of the rinsed resin-bearing material (H-08 BEAD G) and the wet KECOMP sludge material used as starting materials in these tests are given in Table 2 . The quantities of radiochemicals present in each test (bottom, Table 2) were calculated based on the weights of the wet starting solids (Table 1) and the solids concentration data (top, Table 2). The analytical data show the wet KECOMP sludge to be about 400 times more concentrated in uranium than the washed $\mathrm{H}$ $08 \mathrm{BEAD} \mathrm{G}$ and 1000 to 800 times more concentrated in plutonium and americium. However, the KECOMP sludge is only about 10 times more concentrated in ${ }^{137} \mathrm{Cs}$, indicating the extensive (and expected) cesium loading on the resin and zeolite solids.

As shown in Table 2, both the total alpha and the combined ${ }^{238,239,240} \mathrm{Pu}$ and ${ }^{241}$ Am concentrations in the washed and dry resin-bearing material, $\mathrm{H}-08 \mathrm{BEAD} \mathrm{G}$, are about $350 \mathrm{nCi}$ per gram. The TRU concentrations in the rinsed and dried $\mathrm{H}-08$ samples prepared in the previous scoping tests were 
somewhat higher, ranging from 650 to $840 \mathrm{nCi} / \mathrm{g}$ (Schmidt et al. 1999). This may indicate that more thorough removal of non-resin constituents was accomplished in the present tests.

Table 2. Radiochemical Concentrations and Quantities in the Starting Materials

\begin{tabular}{|c|c|c|c|c|c|c|}
\hline \multirow[b]{2}{*}{ Solid } & \multicolumn{6}{|c|}{ Concentration in Wet Solids } \\
\hline & $\begin{array}{l}{ }^{137} \mathrm{Cs}, \\
\mu \mathrm{Ci} / \mathrm{g}\end{array}$ & $\begin{array}{c}\mathrm{U}, \\
\mu \mathrm{g} / \mathrm{g}\end{array}$ & $\begin{array}{c}{ }^{239,240} \mathrm{Pu} \\
\mathrm{nCi} / \mathrm{g}\end{array}$ & $\begin{array}{l}{ }_{\mathrm{nCi}}^{24 / \mathrm{Am}} \\
\mathrm{n}\end{array}$ & $\begin{array}{c}{ }^{238} \mathrm{Pu} /{ }^{241} \mathrm{Am}, \\
\mathrm{nCi} / \mathrm{g}\end{array}$ & $\begin{array}{l}\text { Total Alpha, } \\
\text { nCi } / g\end{array}$ \\
\hline $\mathrm{H}-08 \mathrm{BEAD} \mathrm{G}, \mathrm{A}^{*}$ & 49.8 & 949 & 61.4 & 56.3 & 71.7 & 159 \\
\hline $\mathrm{H}-08 \mathrm{BEAD} \mathrm{G}, \mathrm{B}^{*}$ & 45.5 & 1,077 & 94.7 & 81.0 & 101.2 & 177 \\
\hline Avg. A \& B & 47.6 & 1,013 & 71.8 & 68.7 & 86.4 & 168 \\
\hline KECOMP Sludge* & 498.5 & 422,000 & 74,350 & 58,750 & 61,450 & 136,800 \\
\hline & \multicolumn{6}{|c|}{ Concentration in Dry Solids } \\
\hline Avg. A \& B & 102.6 & 2,182 & 168 & 148 & 186 & 362 \\
\hline KECOMP Sludge & 809 & 685,000 & 120,700 & 95,300 & 99,700 & 220,400 \\
\hline \multirow[b]{2}{*}{ Test } & \multicolumn{6}{|c|}{ Calculated Quantity in Test } \\
\hline & $\mu \mathrm{Ci}$ & $\mu \mathrm{g}$ & $\mathrm{nCi}$ & $\mathrm{NCi}$ & $\mathrm{nCi}$ & $\mathrm{nCi}$ \\
\hline$\overline{\text { OIER } 1}$ & 50 & 1,067 & 82 & 72 & 91 & 177 \\
\hline OIER 2 & 64 & 1,365 & 105 & 93 & 117 & 227 \\
\hline OIER 3 & 99 & 33,404 & 5,757 & 4,558 & 4,786 & 10,625 \\
\hline OIER 4 & 76 & 20,410 & 3,484 & 2,761 & 2,904 & 6,439 \\
\hline OIER 5 & $\overline{46}$ & 989 & 76 & 67 & 84 & 164 \\
\hline OIER 6 & 59 & 1,256 & 97 & 85 & 107 & 209 \\
\hline OIER 7 & 68 & 17,157 & 2,920 & 2,315 & 2,436 & 5,398 \\
\hline OIER 8 & 89 & 29,919 & 5,154 & 4,081 & 4,285 & 9,512 \\
\hline
\end{tabular}

The ICP analyses of the wet H-08 BEAD G materials are given in Table 3 and compared with the composition of fresh water-washed Zeolon- $900^{\mathrm{TM}}$ determined in previous testing (Pool et al. 1998). Assuming that the silicon in the H-08 BEAD G arises solely from the Zeolon- $900^{\mathrm{TM}}$, the zeolite represents about $14.4 \%$ of the H-08 BEAD G material (wet basis) or about $27 \%$ of the dry weight. This amount seems reasonable given the visible appearance of the starting material.

The aluminum and iron remaining in the $\mathrm{H}-08$ BEAD G solids after deducting the Zeolon $-900^{\mathrm{TM}}$ contribution are shown in Table 3 . These elements are unlikely constituents of the organic resin and may represent inorganic particles (sludge) not removed by water washing. The amounts of aluminum and iron found in acid-digested $\mathrm{H}-08$ sample from the original characterization analyses are shown in Table 3 (Welsh et al. 1996). Judging by the comparative amounts of aluminum and iron, water washing appears to have removed $100 \% \times(15,100-5,540) /(15,100)=63 \%$ (iron basis) to $77 \%$ (aluminum basis) of the sludge particles originally present in the H-08 sample.

The H-08 sample was retrieved near the edge of the K East Basin (and away from the corroding uranium fuel in the open canisters). If the non-resin, non-zeolite component associated with this sample is considered to have a composition similar to other sludges near the $\mathrm{K}$ East Basin walls (and be low in uranium concentration like $\mathrm{H}-08$ ), one could estimate the amount of plutonium and americium brought 
Table 3. Metal Concentrations in Solids

\begin{tabular}{|c|c|c|c|c|c|c|c|}
\hline \multirow{2}{*}{ Solid } & \multicolumn{7}{|c|}{ Concentration in Solids, $\mu \mathrm{g} / \mathrm{g}$} \\
\cline { 2 - 8 } & $\mathrm{Al}$ & $\mathrm{Ca}$ & $\mathrm{Fe}$ & $\mathrm{Mg}$ & $\mathrm{Na}$ & $\mathrm{Si}$ & $\mathrm{Ti}$ \\
\hline H-08 BEAD G, A (wet) & 12,800 & 11,200 & 3,950 & 1,660 & 30,500 & 47,400 & 240 \\
\hline H-08 BEAD G, B (wet) & 12,550 & 10,380 & 4,240 & 1,725 & 29,550 & 45,200 & 239 \\
\hline Avg. A \& B & 12,700 & 10,790 & 4,100 & 1,690 & 30,000 & 46,300 & 240 \\
\hline Zeolon-900TM & 69,000 & -- & 4,300 & -- & $\begin{array}{c}\text { Not } \\
\text { analyzed }\end{array}$ & 321,000 & - \\
\hline $\begin{array}{l}\text { H-08 BEAD G (wet) } \\
\text { Minus Zeolon-900 }\end{array}$ & 2,720 & -- & 3,470 & -- & -- & 0 & - \\
\hline $\begin{array}{l}\text { H-08 BEAD G } \\
\text { Minus Zeolon-900 } \\
\text { (dry basis) }\end{array}$ & 4,340 & -- & 5,540 & -- & -- & -- & - \\
\hline H-08 (dry basis) & 18,700 & -- & 15,100 & -- & -- & - & -- \\
\hline
\end{tabular}

by the remaining adhering sludge to the $\mathrm{H}-08$ BEAD G sample. Samples F-10, K-12, and I-15 meet the requirements of low-uranium samples taken from near the basin wall. For these four samples, the average ${ }^{239,240} \mathrm{Pu} / \mathrm{Fe}$ ratio is $8,440 \mathrm{nCi} / \mathrm{g}$; the average ${ }^{241} \mathrm{Am} / \mathrm{Fe}$ ratio is $8,510 \mathrm{nCi} / \mathrm{g}$ (data derived from Welsh et al. 1996). The amount of these radioelements brought to the dry H-08 BEAD G are then

$$
\begin{gathered}
(5,540 \mu \mathrm{g} \mathrm{Fe} / \mathrm{g} \text { dry } \mathrm{H}-08 \mathrm{BEAD} \mathrm{G}) \times\left(8.44 \times 10^{-3} \mathrm{nCi}^{239,240} \mathrm{Pu} / \mu \mathrm{g} \mathrm{Fe}\right) \\
=47 \mathrm{nCi}^{239,240} \mathrm{Pu} / \mathrm{gram} \text { dry } \mathrm{H}-08 \mathrm{BEAD} \mathrm{G}
\end{gathered}
$$

and, similarly, $47 \mathrm{nCi}{ }^{241} \mathrm{Am} / \mathrm{gram}$ dry $\mathrm{H}-08$. These values compare with 168 and $148 \mathrm{nCi} / \mathrm{g}$, respectively, for ${ }^{239,240} \mathrm{Pu}$ and ${ }^{241} \mathrm{Am}$ in the dry H-08 BEAD G (Table 2). The relative values suggest that about $1 / 3$ of the TRU activity $\mathrm{H}-08 \mathrm{BEAD} \mathrm{G}$ could be associated with the iron-bearing sludge particles.

For the as-received $\mathrm{H}-08$,

$$
\left(15,100 \mu \mathrm{g} \mathrm{Fe} / \mathrm{g} \text { dry H-08) } \times\left(8.44 \times 10^{-3} \mathrm{nCi}^{239,240} \mathrm{Pu} / \mu \mathrm{g} \mathrm{Fe}\right)=127 \mathrm{nCi}^{239,240} \mathrm{Pu} / \mathrm{gram}\right. \text { dry H-08 }
$$

and $129 \mathrm{nCi}^{241} \mathrm{Am} / \mathrm{gram}$ dry $\mathrm{H}-08$, accounting for nearly all the actinide associated with the $\mathrm{H}-08$ sample.

The conclusions on the H-08 BEAD G and H-08 material composition drawn from these calculations are highly speculative, however, given the many assumptions. More careful characterizations the $\mathrm{H}-08$ sample and its washed derivatives are required to understand more precisely the contributions of resin, zeolite, and iron-bearing particles to the radioactive inventory of the H-08 material.

\subsection{Leachate Analyses}

The concentrations of radioelements found in the combined leachates and rinses from the first and second leach contacts are presented in Table 4. The concentration data in the replicate tests (OIER 1 and 2, 3 and 4,5 and 6, and 7 and 8) generally compare well in light of the quantities of starting material. However, the concentrations found in the second leach contact in test OIER 5 are substantially higher 
than found in the duplicate OIER 6 test. The analytical preparations and were re-examined but failed to identify the source of the discrepancy. Subsequent material balance studies showed the OIER 5 data to be in error.

Table 4. Radiochemical Concentrations in Test Leachates

\begin{tabular}{|c|c|c|c|c|c|c|c|c|c|c|c|c|}
\hline \multirow[b]{3}{*}{ Test } & \multicolumn{12}{|c|}{ Concentrations in $1^{\text {st }}$ and $2^{\text {nd }}$ Contacts } \\
\hline & \multicolumn{2}{|c|}{$\begin{array}{c}{ }^{\mathrm{IJT}} \mathrm{Cs}, \\
\mu \mathrm{Ci} / \mathrm{mL}\end{array}$} & \multicolumn{2}{|c|}{$\begin{array}{c}\mathrm{U} \\
\mu \mathrm{g} / \mathrm{mL}\end{array}$} & \multicolumn{2}{|c|}{$\begin{array}{l}{ }^{259,240} \mathrm{Pu} \\
\mathrm{nCi} / \mathrm{mL}\end{array}$} & \multicolumn{2}{|c|}{$\begin{array}{c}{ }_{\mathrm{nCi}}^{24 \mathrm{AmL}} \\
\mathrm{nCi}\end{array}$} & \multicolumn{2}{|c|}{$\begin{array}{c}{ }^{238} \mathrm{Pu} /{ }^{241} \mathrm{Am} \\
\mathrm{nCi} / \mathrm{mL}\end{array}$} & \multicolumn{2}{|c|}{$\begin{array}{c}\text { Total Alpha, } \\
\text { nCi/mL }\end{array}$} \\
\hline & $1^{\text {st }}$ & $2^{\text {nd }}$ & $1^{\text {st }}$ & $2^{\text {nd }}$ & $1^{\text {st }}$ & $2^{\text {nd }}$ & $1^{\text {st }}$ & $2^{\text {nd }}$ & $1^{\text {st }}$ & $2^{\mathrm{nO}}$ & $1^{\text {st }}$ & $2^{\text {nd }}$ \\
\hline OIER 1 & $\overline{4.51}$ & 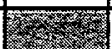 & $\overline{40.0}$ & $\sqrt{8 \times 2}$ & 10.65 & 28 & 15.0 & $\sqrt{3}$ & 16.65 & (1) & 25.1 & \\
\hline OIER 2 & $\overline{4.92}$ & $\sqrt{2 \times 18}$ & 43.4 & (3) & 9.25 & (5) & $\overline{13.2}$ & 2 & 14.6 & 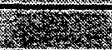 & $\overline{18.7}$ & 1.8. \\
\hline OIER 3 & 8.70 & 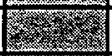 & 5,728 & 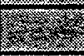 & 732 & 3. & 652 & 20 & 716 & Exy & 1,200 & 6 \\
\hline OIER 4 & $\overline{7.15}$ & 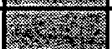 & 1,920 & 36 & 309 & 68 & 269 & texis & 323 & $97 \times 2$ & 486 & (2) \\
\hline OIER 5 & 2.59 & 0.900 & 80.1 & 144 & 6.08 & 13.9 & 8.5 & 10.3 & 9.48 & 12.4 & 16.2 & 29.2 \\
\hline OIER 6 & 2.64 & 0.548 & 78.4 & 57 & 6.49 & 3.3 & 9.4 & 0.51 & 10.4 & 1.02 & 17.7 & 4.16 \\
\hline OIER 7 & 3.38 & 0.926 & 1,830 & 579 & 252 & 147 & 242 & 4.36 & 260 & 21.1 & 511 & 172 \\
\hline OIER 8 & 5.05 & 0.770 & 3,570 & 933 & 513 & 248 & 432 & 7.58 & 498 & 36.6 & 969 & 310 \\
\hline
\end{tabular}

The combined leachate plus rinse volumes were $10 \mathrm{~mL}$ for the Ce(IV) tests (OIER 1 through 4 ), $8 \mathrm{~mL}$ for the first contact in the nitric/oxalic tests (OIER 5 through 8 ), and $7 \mathrm{~mL}$ for the second contact nitric/oxalic tests.

\subsection{Leach Residue Analyses}

The radiochemical concentrations in the leach residues are given in Table 5. The final residue weights also given in Table 5 show that little weight loss occurred by treatment of these samples.

Table 5. Radiochemical Concentrations in Test Residues

\begin{tabular}{|c|c|c|c|c|c|c|c|}
\hline \multirow[b]{2}{*}{ Test } & \multicolumn{6}{|c|}{ Concentration } & \multirow{2}{*}{$\begin{array}{c}\text { Final } \\
\text { Weight, } \\
\text { g }\end{array}$} \\
\hline & $\begin{array}{l}{ }^{15 T} \mathrm{Cs} \\
\mu \mathrm{Ci} / \mathrm{g}\end{array}$ & $\begin{array}{c}\mathrm{U} \\
\mu \mathrm{g} / \mathrm{g}\end{array}$ & $\begin{array}{c}{ }^{239,240} \mathrm{Pu} \\
\mathrm{nCi} / \mathrm{g}\end{array}$ & $\begin{array}{l}{ }_{\mathrm{nCi}}^{24 \mathrm{Am}} \text {, } \\
\mathrm{nCi}\end{array}$ & $\begin{array}{c}{ }^{258} \mathrm{Pu}{ }^{241} \mathrm{Am} \\
n C i / g\end{array}$ & $\begin{array}{c}\text { Total Alpha, } \\
\text { nCi/g }\end{array}$ & \\
\hline OIER 1 & 46.1 & 1,850 & 105 & 65.1 & 81.2 & 206 & 0.4605 \\
\hline OIER 2 & 12.4 & 1,870 & 108 & 55.1 & 71.7 & 155 & 0.6025 \\
\hline OIER 3 & 32.3 & 26,500 & 4,960 & 1,710 & 2,350 & 6,780 & 0.5002 \\
\hline OIER 4 & 20.0 & 10,110 & 1,910 & 688 & 870 & 2,460 & 0.4359 \\
\hline OIER 5 & 35.9 & 920.5 & 20.95 & 81.4 & 84.6 & 102 & 0.3687 \\
\hline OIER 6 & 42.4 & 1,140 & 24.2 & 88.6 & 92.3 & 121 & 0.5021 \\
\hline OIER 7 & 98.7 & 3,490 & 152 & 992 & 1,000 & 1,120 & 0.3894 \\
\hline OIER 8 & 68.6 & 7,080 & 289 & 1,750 & 1,670 & 1,830 & 0.4435 \\
\hline
\end{tabular}

The ${ }^{137} \mathrm{Cs}$ concentrations range from about 12 to $100 \mu \mathrm{Ci} / \mathrm{g}$ or about 12 to $100 \mu \mathrm{Ci} / \mathrm{mL}$ assuming a 1.0 $\mathrm{g} / \mathrm{mL}$ bulk density of the largely resin residue. The ERDF criterion $(32 \mu \mathrm{Ci} / \mathrm{mL})$ is exceeded $2-$ to 3 -fold for ${ }^{137} \mathrm{Cs}$ in the nitric/oxalic acid tests with added sludge. The Ce(IV) leach (tests OIER 1 through 4), with its higher nitric acid concentration, achieves better ${ }^{137} \mathrm{Cs}$ decontamination and produces solids near the ERDF ${ }^{137} \mathrm{Cs}$ criterion. 
The TRU (total alpha) concentrations in the residues from tests without added sludge were near the ERDF 100-nCi/g limit. With added sludge, the ERDF criterion was exceeded 11- to 70-fold. The TRU concentrations in the residues were consistently lower for the nitric/oxalic treatment than for the Ce(IV) treatment. The better performance of nitric/oxalic is almost solely because of its better removal of plutonium. This observation is true for the tests both with and without added sludge.

The plutonium concentrations in the nitric/oxalic acid-treated residues from tests OIER 5 and 6 are below the ERDF criteria of $29 \mathrm{nCi} / \mathrm{mL}$ each for ${ }^{239} \mathrm{Pu}$ and ${ }^{240} \mathrm{Pu}$. Because ${ }^{240} \mathrm{Pu}$ represents about $1 / 3$ of the ${ }^{239,240} \mathrm{Pu}$ activity in $\mathrm{K}$ Basin materials, and the ERDF activity concentration limits for ${ }^{239} \mathrm{Pu}$ and ${ }^{240} \mathrm{Pu}$ are identical, the ${ }^{239} \mathrm{Pu}$ limit is the more restrictive for ERDF disposal acceptance. The ${ }^{239} \mathrm{Pu}$ limit is exceeded about 3- to 7-fold for the residues from nitric/oxalic acid tests OIER 7 and 8 containing the added sludge.

Americium concentrations in the residues were not strongly dependent on the treatment used. The americium concentrations from the nitric/oxalic acid treatment are up to 1.8 times the $50 \mathrm{nCi} / \mathrm{mL}$ ERDF limit in the tests without added sludge and up to 35 times the ERDF limit in the tests with sludge.

Uranium decontamination was better for the nitric/oxalic treatment than for the $\mathrm{Ce}$ (IV) treatment. The ERDF criterion for uranium $(2,600 \mu \mathrm{g} / \mathrm{mL})$ was exceeded 1.4 - to 10 -fold for the tests having added sludge; the tests without sludge were about half the ERDF limits.

\subsection{Material Balances}

The radiochemical material balances for the leach tests are given in Tables 6 through 11 for ${ }^{137} \mathrm{Cs}, \mathrm{U}$, ${ }^{239,240} \mathrm{Pu},{ }^{241} \mathrm{Am},{ }^{238} \mathrm{Pu} /{ }^{241} \mathrm{Am}$, and total alpha, respectively. The material balances compare the quantities of radiochemicals found in the weighed amounts of starting $\mathrm{K}$ Basin sludge materials (H-08 BEAD G and KECOMP) with the sum of the quantities found in the leach test fractions $\left(1^{\text {st }}\right.$ contact, $2^{\text {nd }}$ contact, and solids residue). The ratios of the sum found to the amount in the start, expressed as \% recovery, also are given in Tables 6 to 11 .

In general, the amounts found in the leachates and residues exceed the nominal starting amount: The anomalous high amounts of radiochemical in the second leach contact of OIER 5 also are clearly evident. Based on the material balance data, the data for the second leach contact in test OIER 5 are questionable. Therefore, results using the data from the second leach contact of test OIER 5 likely are incorrect and data derived form the duplicate test OIER 6 must be used.

Table 6. Leach Testing Material Balance for ${ }^{137} \mathrm{Cs}$

\begin{tabular}{|c|c|c|c|c|c|c|}
\hline \multirow{2}{*}{ Test } & \multicolumn{7}{|c|}{${ }^{137} \mathrm{Cs}, \mu \mathrm{Ci}$} \\
\cline { 2 - 7 } & Start & Sum & $\%$ Recovery & $1^{\text {st }}$ Contact & $2^{\text {nd }}$ Contact & Residue \\
\hline OIER 1 & 50 & 66.3 & 132.2 & 45.1 & & \\
\hline OIER 2 & 64 & 56.7 & 88.3 & 49.2 & & 21.2 \\
\hline OIER 3 & 99 & 103.2 & 104.6 & 87 & & 7.5 \\
\hline OIER 4 & 76 & 80.2 & 106.0 & 71.5 & & 16.2 \\
\hline OIER 5 & 46 & 40.3 & 86.6 & 20.72 & 6.3 & 8.7 \\
\hline OIER 6 & 59 & 46.2 & 78.3 & 21.12 & 3.836 & 21.3 \\
\hline OIER 7 & 68 & 72.0 & 106.2 & 27.04 & 6.482 & 38.4 \\
\hline OIER 8 & 89 & 76.2 & 85.2 & 40.4 & 5.39 & 30.4 \\
\hline
\end{tabular}


Table 7. Leach Testing Material Balance for Uranium

\begin{tabular}{|c|c|c|c|c|c|c|}
\hline \multirow{2}{*}{ Test } & \multicolumn{5}{|c|}{ Uranium, $\mu \mathrm{g}$} \\
\cline { 2 - 7 } & Start & Sum & \% Recovery & $1^{\text {st }}$ Contact & $2^{\text {nd }}$ Contact & Residue \\
\hline OIER 1 & 1,067 & 1,252 & 117.3 & 400 & & 851.9 \\
\hline OIER 2 & 1,365 & 1,561 & 114.3 & 434 & & 1,127 \\
\hline OIER 3 & 33,404 & 70,530 & 211.1 & 57,275 & & 13,255 \\
\hline OIER 4 & 20,410 & 23,607 & 115.7 & 19,200 & & 4,407 \\
\hline OIER 5 & 989 & 1,988 & 201.1 & 640.8 & 1,008 & 339.4 \\
\hline OIER 6 & 1,256 & 1,599 & 127.2 & 627.2 & 399 & 572.4 \\
\hline OIER 7 & 17,157 & 20,052 & 116.9 & 14,640 & 4,053 & 1,359 \\
\hline OIER 8 & 29,919 & 38,231 & 127.8 & 28,560 & 6,531 & 3,140 \\
\hline
\end{tabular}

Table 8. Leach Testing Material Balance for ${ }^{239,240} \mathrm{Pu}$

\begin{tabular}{|c|c|c|c|c|c|c|}
\hline \multirow{2}{*}{ Test } & \multicolumn{7}{|c|}{${ }^{239,740} \mathrm{Pu}, \mathrm{nCi}$} \\
\cline { 2 - 7 } & Start & End & $\%$ Recovery & $1^{\text {st }}$ Contact & $2^{\text {nd }}$ Contact & Residue \\
\hline OIER 1 & 82 & 154.9 & 188.3 & 106.5 & & \\
\hline OIER 2 & 105 & 157.6 & 149.7 & 92.5 & & 48.4 \\
\hline OIER 3 & 5,757 & 9,801 & 170.2 & 7,320 & & 65.1 \\
\hline OIER 4 & 3,484 & 3,923 & 112.6 & 3,090 & & 2,481 \\
\hline OIER 5 & 76 & 153.7 & 201.6 & 48.64 & 97.3 & 7.7 \\
\hline OIER 6 & 97 & 87.2 & 90.0 & 51.92 & 23.1 & 12.2 \\
\hline OIER 7 & 2,920 & 3,104 & 106.3 & 2,016 & 1,029 & 59.2 \\
\hline OIER 8 & 5,154 & 5,968 & 115.8 & 4,104 & 1,736 & 128.2 \\
\hline
\end{tabular}

Table 9. Leach Testing Material Balance for ${ }^{241} \mathrm{Am}$

\begin{tabular}{|c|c|c|c|c|c|c|}
\hline \multirow{2}{*}{ Test } & \multicolumn{7}{|c|}{ ¿41 $\mathrm{Am}, \mathrm{nCi}^{\text {nCi }}$} \\
\cline { 2 - 8 } & Start & End & \% Recovery & $1^{\text {st }}$ Contact & $2^{\text {nd }}$ Contact & Residue \\
\hline OIER 1 & 72 & 180.1 & 249.0 & 150.2 & & 30.0 \\
\hline OIER 2 & 93 & 165.0 & 178.3 & 131.8 & & 33.2 \\
\hline OIER 3 & 4,558 & 7,375 & 161.8 & 6,520 & & 855.3 \\
\hline OIER 4 & 2,761 & 2,990 & 108.3 & 2,690 & & 299.9 \\
\hline OIER 5 & 67 & 170.3 & 254.0 & 68.4 & 71.9 & 30.0 \\
\hline OIER 6 & 85 & 123.3 & 144.8 & 75.2 & 3.6 & 44.5 \\
\hline OIER 7 & 2,315 & 2,353 & 101.7 & 1,936 & 30.5 & 386.3 \\
\hline OIER 8 & 4,081 & 4,285 & 105.0 & 3,456 & 53.1 & 776.1 \\
\hline
\end{tabular}


Table 10. Leach Testing Material Balance for ${ }^{238} \mathrm{Pu} /{ }^{241} \mathrm{Am}$

\begin{tabular}{|c|c|c|c|c|c|c|}
\hline \multirow{2}{*}{ Test } & \multicolumn{7}{|c|}{${ }^{238} \mathrm{Pu}{ }^{241} \mathrm{Am}, \mathrm{nCi}$} & & \\
\cline { 2 - 7 } & Start & End & $\%$ Recovery & $1^{\text {st }}$ Contact & $2^{\text {nd }}$ Contact & Residue \\
\hline OIER 1 & 91 & 203.9 & 223.9 & 166.5 & & 37.4 \\
\hline OIER 2 & 117 & 189.2 & 162.4 & 146 & & 43.2 \\
\hline OIER 3 & 4,786 & 8,336 & 174.1 & 7,160 & & 1,176 \\
\hline OIER 4 & 2,904 & 3,609 & 124.3 & 3,230 & & 379.2 \\
\hline OIER 5 & 84 & 193.8 & 229.7 & 75.84 & 86.8 & 31.2 \\
\hline OIER 6 & 107 & 136.7 & 127.5 & 83.2 & 7.14 & 46.3 \\
\hline OIER 7 & 2,436 & 2,617 & 107.4 & 2,080 & 147.7 & 389.4 \\
\hline OIER 8 & 4,285 & 4,981 & 116.2 & 3,984 & 256.2 & 740.6 \\
\hline
\end{tabular}

Table 11. Leach Testing Material Balance for Total Alpha

\begin{tabular}{|c|c|c|c|c|c|c|}
\hline \multirow{2}{*}{ Test } & \multicolumn{7}{|c|}{ Total Alpha, nCi } \\
\cline { 2 - 7 } & Start & Sum & \% Recovery & $1^{\text {st }}$ Contact & $2^{\text {nd }}$ Contact & Residue \\
\hline OIER 1 & 177 & 345.9 & 195.2 & 251 & & 94.9 \\
\hline OIER 2 & 227 & 280.4 & 123.6 & 187 & & 93.4 \\
\hline OIER 3 & 10,625 & 15,391 & 144.9 & 12,000 & & 3,391 \\
\hline OIER 4 & 6,439 & 5,932 & 92.1 & 4,860 & & 1,072 \\
\hline OIER 5 & 164 & 371.6 & 226.3 & 129.6 & 204.4 & 37.6 \\
\hline OIER 6 & 209 & 231.5 & 110.9 & 141.6 & 29.12 & 60.8 \\
\hline OIER 7 & 5,398 & 5,728 & 106.1 & 4,088 & 1,204 & 436.1 \\
\hline OIER 8 & 9,512 & 10,734 & 112.8 & 7,752 & 2,170 & 811.6 \\
\hline
\end{tabular}

\subsection{Decontamination Factors}

The solids decontamination factors (DFs), based on dry solids weights, are shown in Table 12. The DF is the ratio of the concentration of the analyte of interest in the starting material to its concentration in the residue. The DFs calculated based on wet solids weights would be similar because the water retention by resin (which constitutes the bulk of the solids) would be similar for the untreated and leached materials.

Table 12. Decontamination Factors for Solids

\begin{tabular}{|c|c|c|c|c|c|c|}
\hline Test & t5T $\mathrm{Cs}$ & Uranium & ${ }^{239,240} \mathrm{Pu}$ & ${ }^{241} \mathrm{Am}$ & ${ }^{258} \mathrm{Pu} /{ }^{241} \mathrm{Am}$ & Total Alpha \\
\hline$\overline{\text { OIER } 1}$ & 2.9 & 1.4 & 3.0 & 5.7 & 5.1 & 3.4 \\
\hline OIER 2 & 7.3 & 1.3 & 2.3 & 4.8 & 4.2 & 2.9 \\
\hline OIER 3 & $\overline{5.4}$ & 4.5 & 3.3 & 7.3 & 6.0 & 3.8 \\
\hline OIER 4 & 7.8 & 4.5 & 4.0 & 8.4 & 8.1 & 4.7 \\
\hline OIER 5* & 24 & 48 & 962 & 4. 6 & 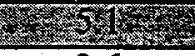 & 80 \\
\hline OIER 6 & 1.9 & 2.4 & 6.3 & 2.4 & 2.6 & 3.3 \\
\hline OIER 7 & 1.5 & 12.1 & 43.0 & 5.0 & 5.5 & 10.8 \\
\hline OIER 8 & 2.1 & 10.0 & 38.2 & 4.5 & 5.5 & 10.8 \\
\hline
\end{tabular}

The superior Pu DFs (around 40) for the nitric/oxalic leachant are clearly evident for the tests with sludge (tests OIER 7 and 8) but less distinct in the test with resin/zeolite alone (OIER 6; DF is about 6). This may indicate that some core amount of $\mathrm{Pu}$ is tightly bound with the resin or zeolite and not 
available for elution. The nitric/oxalic treatment also works better than $\mathrm{Ce}$ (IV) for removal of uranium. Cesium and americium DFs are slightly better for the Ce(IV) tests, perhaps because of the higher acid concentration ( $6 \underline{\mathrm{M}}$ versus $4 \underline{\mathrm{M}}$ in the nitric/oxalic acid tests). The higher acid concentration favors displacement of these elements from the cationic resin. Because neither element forms anionic species in strong nitric acid, retention on the anion resin should be low.

\subsection{Distribution Coefficients}

Distribution coefficients $\left(\mathrm{K}_{d} \mathrm{~s}\right)$ are the ratios of the concentration of an analyte of interest in the solid phase, per gram, to the concentration of the analyte found in the equilibrium solution, per milliliter. The $\mathrm{K}_{\mathrm{d}} \mathrm{S}$ of the six analytes of interest for the OIER 1 through OIER 8 tests are given in Table 13 in units of $\mathrm{mL} / \mathrm{g}$. The $\mathrm{K}_{\mathrm{d}} \mathrm{s}$ are calculated on the basis of wet solids. The values would increase about a factor of 2 on a dry solids basis. To calculate the $\mathrm{K}_{\mathrm{d}} \mathrm{s}$ for the first contact in tests OIER 5 through 8 , the quantity of activity on the solid phase after the first contact must be known. This quantity was taken to be the sum of the analyte contained in the second leach contact and in the final residue.

Table 13. Distribution Coefficients

\begin{tabular}{|c|c|c|c|c|c|c|c|}
\hline \multirow{2}{*}{\begin{tabular}{|c|}
$1^{\text {st }}$ Contact \\
Test
\end{tabular}} & \multirow[b]{2}{*}{ Leachant } & \multicolumn{6}{|c|}{ Distribution Coefficient $\left(\mathrm{K}_{\mathrm{d}}\right), \mathrm{mL} / \mathrm{g}$} \\
\hline & & ${ }^{15 T} \mathrm{Cs}$ & Uranium & ${ }^{239,240} \mathrm{Pu}$ & ${ }^{241} \mathrm{Am}$ & ${ }^{258} \mathrm{Pu} /{ }^{241} \mathrm{Am}$ & Total Alpha \\
\hline OIER 1 & \multirow{4}{*}{$\begin{array}{l}6 \mathrm{M} \mathrm{HNO}_{3} / \\
0.4 \underline{\mathrm{M} \mathrm{Ce}} \text { (IV) }\end{array}$} & 4.5 & 20.2 & 4.3 & 1.9 & 2.1 & 3.6 \\
\hline OIER 2 & & 1.1 & 19.3 & 5.2 & 1.9 & 2.2 & 3.7 \\
\hline OIER 3 & & 1.5 & 1.8 & 2.7 & 1.0 & 1.3 & 2.2 \\
\hline OIER 4 & & 1.1 & 2.1 & 2.4 & 1.0 & 1.1 & 2.0 \\
\hline OIER 5 & \multirow[t]{4}{*}{$4 \underline{\mathrm{MHNO}} \mathrm{HN}_{3}$} & 272 & 172 & 1779 & 1.2. & 2128 & 933 \\
\hline OIER 6 & & 7.7 & 10.0 & 4.4 & 4.1 & 4.1 & 4.1 \\
\hline OIER 7 & & 13.0 & 2.9 & 4.2 & 1.7 & 2.0 & 3.1 \\
\hline OIER 8 & & 6.1 & 2.3 & 3.1 & 1.6 & 1.7 & 2.6 \\
\hline \multirow{2}{*}{$\begin{array}{l}2^{\text {nd }} \text { Contact } \\
\text { Test }\end{array}$} & \multirow[b]{2}{*}{ Leachant } & \multicolumn{6}{|c|}{ Distribution Coefficient $\left(\mathrm{K}_{\mathrm{d}}\right), \mathrm{mL} / \mathrm{g}$} \\
\hline & & T57 $\mathrm{Cs}$ & Uranium & ${ }^{239,240} \overline{\mathrm{Pu}}$ & ${ }^{241} \mathrm{Am}$ & ${ }^{238} \mathrm{Pu} /{ }^{241} \mathrm{Am}$ & Total Alpha \\
\hline OIER 5 & \multirow{4}{*}{$\begin{array}{l}0.1 \underline{\mathrm{M}} \mathrm{HNO}_{3} / \\
0.2 \underline{\mathrm{M}} \mathrm{H}_{2} \mathrm{C}_{2} \mathrm{O}_{4}\end{array}$} & 75. & 2419 & 106 & 30 & 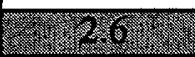 & 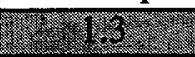 \\
\hline OİER 6 & & 31.3 & 8.1 & 3.0 & 69.8 & 36.6 & 11.8 \\
\hline OIER 7 & & 40.6 & 2.3 & 0.4 & 86.6 & 18.0 & 2.5 \\
\hline OIER 8 & & 33.9 & 2.9 & 0.4 & 87.9 & 17.4 & 2.2 \\
\hline
\end{tabular}

The actinide $\mathrm{K}_{d} \mathrm{~s}$ for test OIER 5 clearly are incorrect because of the incorrect (high) concentrations in the second contact leachate. Cesium $\mathrm{K}_{\mathrm{d}} \mathrm{s}$ decrease, as expected, with increasing acid concentration. Americium $\mathrm{K}_{\mathrm{d}} \mathrm{s}$ are low for the first contact tests at 4 or $6 \mathrm{M} \mathrm{HNO}_{3}$ (indicating the expected low sorption on the cation and anion resin at high acid concentration) but increase sharply (as expected for cation resin sorption) in the $0.1 \mathrm{M} \mathrm{HNO}_{3}$ second contacts. The uranium $\mathrm{K}_{d} s$ in the high acid contacts [6 $\mathrm{HNO}_{3} / 0.4 \underline{\mathrm{M}} \mathrm{Ce}(\mathrm{IV})$ or $4 \underline{\mathrm{M}} \mathrm{HNO}_{3}$ ] are much higher for the tests with $\mathrm{H}-08 \mathrm{BEAD} \mathrm{G}$ alone than in the tests with added KECOMP sludge. Like the case for plutonium, this may point to incorporation of nonelutable or insoluble uranium in the resin/zeolite solids.

Plutonium $\mathrm{K}_{\mathrm{d}} \mathrm{s}$ range from about 2 to $5 \mathrm{~mL} / \mathrm{g}$ and, in leaching, do not strongly favor the $4 \underline{\mathrm{M}} \mathrm{HNO}_{3}$ or the $6 \underline{\mathrm{M}} \mathrm{HNO}_{3} / 0.4 \underline{\mathrm{M}} \mathrm{Ce}(\mathrm{IV})$ contacts. The plutonium $\mathrm{K}_{d} \mathrm{~s}$ are slightly lower with added sludge. This again may indicate that some portion of the plutonium is non-elutable from the resin/zeolite solids. The present $\mathrm{K}_{d}$ results compare with plutonium $\mathrm{K}_{d}$ s found previously of 58 to $86 \mathrm{~mL} / \mathrm{g}$ for $\mathrm{H}-08$ alone and 4.0 to 5.6 for $\mathrm{H}-08$ with added canister sludge in $10 \underline{\mathrm{M} ~ \mathrm{HNO}_{3}}$ (Schmidt et al. 1999). The prior tests again show the difference in the $\mathrm{K}_{d} \mathrm{~s}$ found with and without added sludge; this difference is even greater 
than observed in the present tests. The sharply lower $\mathrm{K}_{\mathrm{d}} \mathrm{s}$ in the dilute nitric/oxalic acid contacts for the tests with added sludge show the effectiveness of this reagent in leaching plutonium. The $\mathrm{K}_{\mathrm{d}}$ of $3.0 \mathrm{~mL} / \mathrm{g}$ for plutonium in the OIER 6 test, compared with the $\mathrm{K}_{d}$ of $0.4 \mathrm{~mL} / \mathrm{g}$ in tests OIER 7 and 8 , once again shows that some plutonium present in the solids resists elution even with nitric/oxalic acid.

Separate calculations find the amount of non-elutable uranium to be about $315 \mu \mathrm{g}$ per gram wet H-08 BEAD G. For plutonium, the non-elutable concentration is about $8.5 \mathrm{nCi}^{239,240} \mathrm{Pu} / \mathrm{gram}$ wet solid. Further multiple exhaustive leaching contacts must be performed to verify the existence and amounts of the postulated non-elutable uranium and plutonium.

\subsection{Dissolution Coefficients}

The fractions of analyte dissolved in the various leach treatments are given in Table 14. These fractions are calculated by dividing the quantity reporting to solution (in the leachate) by the total quantity present in the leach test (leachate plus residue). These data are given in Tables 6 through 11 for ${ }^{137} \mathrm{Cs}, \mathrm{U}$, ${ }^{239,240} \mathrm{Pu},{ }^{241} \mathrm{Am},{ }^{238} \mathrm{Pu} /{ }^{241} \mathrm{Am}$, and total alpha, respectively.

Table 14. Dissolution Coefficients

\begin{tabular}{|c|c|c|c|c|c|c|}
\hline Test & ${ }^{13} \mathrm{Cs}$ & Uranium & ${ }^{239} \mathrm{Pu}$ & ${ }^{241} \mathrm{Am}$ & ${ }^{238} \mathrm{Pu} /{ }^{241} \mathrm{Am}$ & Total Alpha \\
\hline OIER 1 & 0.680 & 0.320 & 0.688 & 0.834 & 0.817 & 0.834 \\
\hline OIER 2 & 0.868 & 0.278 & 0.587 & 0.799 & 0.772 & 0.799 \\
\hline OIER 3 & 0.843 & 0.812 & 0.747 & 0.884 & 0.859 & 0.884 \\
\hline OIER 4 & 0.891 & 0.813 & 0.788 & 0.900 & 0.895 & 0.900 \\
\hline OIER 5 & 0.671 & 0.829 & 0.950 & 0.824 & 0.839 & 0.824 \\
\hline OIER 6 & 0.540 & 0.642 & 0.861 & 0.639 & 0.661 & 0.639 \\
\hline OIER 7 & 0.466 & 0.932 & 0.981 & 0.836 & 0.851 & 0.836 \\
\hline OIER 8 & 0.601 & 0.918 & 0.979 & 0.819 & 0.851 & 0.819 \\
\hline
\end{tabular}




\subsection{References}

ERDF 1997. ERDF Waste Acceptance Criteria, BHI-00139, Rev. 2, Table 4-1.

Flament, T.A. 1998. Testing Strategy to Support the Development of $K$ Basin Sludge Treatment Process, HNF-2574, Rev.0, Numatec Hanford Company, Richland, Washington.

Dodd, D.A. 1998. Engineering Study: Recommendation for Removing Radionuclides from Organic Ion Exchange Resin in K Basin Sludge, HNF-2802, July, 1998, Numatec Hanford Company, Richland, Washington.

Pool, K.H. C.H. Delegard, A.J. Schmidt, B.M. Thornton, and K.L. Silvers. 1998. Results from Test 4, "Acid Digestion of Mixed-Bed Ion Exchange Resin, PNNL-12107, Pacific Northwest National Laboratory, Richland, Washington.

Reas, W.H. 1949. "Identification of Plutonium(IV) Oxalate Complexes in Oxalic Acid Solutions." paper 4.9 in The Transuranium Elements, G.T. Seaborg, J.J. Katz, and W.M. Manning (editors), McGraw-Hill Book Company, New York.

Roberts, F.P. 1963. Separation of Cerium by Anion Exchange, HW-SA-3082. Hanford Atomic. Products Operation, General Electric Company, Richland, Washington.

Ryan, J.L. 1972. "Anion Exchange Reactions." chapter 4.7.3 in Vol. 71 of Gmelin's Handbook of Inorganic Chemistry, The Transuranium Elements. Verlag Chemie G.m.g.h., Weinheim, Germany.

Schmidt, A.J., G.S. Klinger, and P.R. Bredt. 1998. Evaluation of Ion Exchange Materials in K Basin Floor Sludge and Potential Solvents for PCB Extraction from Ion Exchange Materials, PNNL-12108, Pacific Northwest National Laboratory, Richland, Washington.

Schmidt, A. J., K. L. Silvers, P. R. Bredt, C. H. Delegard, E. W. Hoppe, J. M. Tingey, A. H. Zacher, T. L. Welsh, and R. B. Baker. 1999. "Supplementary Information on K-Basin Sludges." HNF-2367, Rev. 0. Fluor Daniel Hanford, Inc., Richland, Washington.

Welsh, T.L., R.B. Baker, D.R. Hansen, G.R. Golcar, and B.J. Makenas. 1996. Analysis of Sludge from Hanford K East Basin Floor and Weasel Pit, WHC-SP-1182, Appendix D, Westinghouse Hanford Company, Richland, Washington. 